\title{
Discussion on the Innovative Approach to the Teaching Discourse System of Ideological and Political Academics
}

\author{
Xiaoliang Guo ${ }^{1}$ Long $\mathrm{Xia}^{2, *}$ \\ ${ }^{1}$ School of Marxism, Harbin Institute of Technology at Weihai, Weihai, Shandong, China \\ ${ }^{2}$ School of Materials Science and Engineering, Harbin Institute of Technology at Weihai, Weihai, Shandong, \\ China \\ *Corresponding author. Email: xialong@hit.edu.cn
}

\begin{abstract}
In view of the problems existing in the discourse system of course teaching in colleges and universities in the new era, this paper analyzes the content system, teaching mode, discourse expression mode and teaching effect, and it also tries to explore the innovation path of discourse teaching system in colleges and universities from the aspects of integrating teaching content, changing teaching mode, enriching discourse expression mode and optimizing the operational of practice.
\end{abstract}

Keywords: Discourse, Discourse system, Teaching discourse mode.

\section{INTRODUCTION}

Thinking and studying the problems existing in the teaching discourse system of ideological and political course in colleges and universities, exploring the innovation path of teaching discourse system of course teachers in colleges and universities and improving the pertinence and timeliness of teaching continuously are conducive to constructing a scientific, reasonable and effective discourse system of ideological and political courses, so as to better play the role in building morality and cultivating people.

\section{THE CONNOTATION OF} DISCOURSE, DISCOURSE SYSTEM AND THE DISCOURSE SYSTEM OF IDEOLOGICAL AND POLITICAL TEACHERS IN COLLEGES AND UNIVERSITIES

"Discourse" was originally a linguistic term. "Later, in the 20th century, Michel Foucault, a French philosopher, extended the term to the field

*Fund: "Research on the Reform of Case Teaching Mode of Ideological and Political Course Based on OBE Concept" Teaching Reform and Innovation Project of Marxist College of Harbin Institute of Technology (Weihai) of sociology history, which gave the word "discourse" a vivid color of historical sociology, therefore, in his opinion, "discourse" isn't what the "language" can contain, but it is "an expression which includes moral thinking, knowledge and science and text talking or an even more tendentious expression".

The discourse system is generally believed to be composed of three parts: the subject of "who says", the object of "what to say", and the method of "how to say".

The discourse system of teachers in colleges and universities is an expression system used by teachers in the process of theory teaching and researching in colleges and universities, which is based on the aim of education and follows certain rules of discourse, using word, sound waves, gestures and other symbols to constitute and which also reflects the ideas, positions, methods and value orientation of a new era. 


\section{THE PROBLEMS EXISTING IN TEACHING DISCOURSE INNOVATION OF TEACHERS IN COLLEGES AND UNIVERSITIES}

\subsection{The Content System of Traditional Discourse Is Old, Being Lacking of Epochal Character and Out of Touch with Reality}

Over the past 40 years of reform and opening up, with the rapid development of market economy and the earth-shaking changes of society, the content of course teaching discourse has also changed with each passing day. In real practice, there are still some problems, for example, the generality of textbook's content is too strong; the language is rigid and the reality is not harmonious, which are inconvenient for both the teachers to teach and the students to read. Therefore, most of the teachers still use the out-dated and oldfashioned textbook discourse and propaganda discourse to teach, but they don't keep pace with times. Or the course's content is updated but the cases are not, also, their content is still outdated and the theory is still hard to understand, which makes the students confused and the effect of teaching reduced.

The rapid development of information and technology in the new media era makes the traditional discourse content form fractured new features. The traditional discourse dilemma which is content-single, boring and rigid leads to the disconnection with reality. The traditional teaching discourse content of teachers is not able to meet the need and psychological expectations of students and even not able to meet the personalized characteristics of students. As what has been discussed above, the discourse has social historicity and it has different characters in different period. The historical characteristics of the new era, the use of new media and other methods require us to innovate the discourse system of the ideological and political course. And first of all, we need to change thoroughly in the aspects of the innovative integration and transformation of teaching discourse content.

\subsection{The Infusing Teaching Discourse Mode Is Serious and Needs To Be Changed}

In today's ideological and political teaching, teachers mostly use the same or similar courseware.
The teachers have the discourse hegemony and they just hold a "one way of talking" mode. This method neglects students' individual differences which are caused by growth environment, professional attributes and emotional cognition. This can easily lead to the single mode such as "one size fits all" and "the same for thousands". Monopolizing the power of discourse is also very easy to cause the "monologue" teaching mode also lack of humanistic care and cultivation of students, thus resulting in poor teaching effect.

The new era calls for the reform and innovation of various forms of teaching discourse mode, such as "heuristic" and "interactive" mode.

\subsection{The Traditional Teaching Discourse Expression Is Simple and Boring, and It Is Easy to Fall into the "Preaching" Discourse Dilemma}

Habermas' communicative behavior theory points out that communication is the final goal of human's language. He defined communication as a process where the subjects with speech and behavior abilities reach an agreement with each other. In the process of teaching activities, teachers and students belong to a two-way interactive communication mode, which is based on equal dialogue, opening their hearts, interacting with each other, and exchanging ideas. Then it can lead to the consensus in the ideas, emotions and wills of teachers and students in the communication and get sublimation in thought. Therefore, in the practical teaching activities, the dominant teacher's discourse expression ability directly affects the classroom effect. Many teachers have done a good job in grasping the contents of the teaching materials. However, they are not satisfied with how to express the contents into the best effect. On the contrary, there is an embarrassing situation that "the teacher talks too much and the students fall asleep so quickly when listening to them".

In the practical teaching activities, the dominant teacher's discourse expression ability directly affects the classroom effect. Many teachers have done a good job in grasping the contents of the teaching materials. However, they are not satisfied with how to express the contents into the best effect. On the contrary, there is an embarrassing situation that "the teacher talks too much and the students fall asleep so quickly when listening to them". 


\subsection{The Effect of Externalized Practice Teaching Is Worrying}

Now, the practical teaching in the course reform in colleges and universities contains class practice teaching, school practice teaching and outside practice teaching. Practice teaching exists in the form of classroom question and answer, after class games, debate and discussion, extracurricular visit, investigation and investigation, etc., which is superficial and formalized. Students obey the unified arrangement, but they have no time to think in the process of action and lack of rational analysis, which will inevitably affect the effectiveness of teaching practice. In the final analysis, the course is an educational project related to the long-term development of students. It affects the shaping of students' inner world outlook, outlook on life and values, and focuses on the transformation of students' inner heart. Only when the students can sink down to read, think and analyze, internalize in the heart, can we achieve the long-term goal. At present, the externalized practice teaching, with obvious characteristics of action and even entertainment, is difficult to achieve the expected effect of college students' identification.

\section{THE INNOVATIVE PATH OF TEACHERS' DISCOURSE TEACHING SYSTEM IN COLLEGES AND UNIVERSITIES}

\subsection{Integration and Innovation of Teaching Discourse Content}

The social historicity of discourse determines that the content of teaching discourse needs to be fully integrated. There are two aspects need to be considered at the same time in the integration of teaching discourse content.

In the content transformation of teaching discourse, it should be transformed from traditional discourse to modern discourse. In the new era, we should guide students to understand the historical inevitability of localization Marxism in China. We should correctly grasp the Mao Zedong Thought, Deng Xiaoping Theory, the important thought of Three Represents and especially $\mathrm{Xi}$ Jinping Thought on Socialism with Chinese Characteristics for a New Era and its historical background, main content, historical position and guiding significance. Through vertical and horizontal comparison, we can manage to build consensus with students and to explain the truth clearly.
John Dewey, an American educator, once said: "Only when students pay attention to other people's thoughts and feelings with sympathy and respect and also they are inspired, can such a class be effective. If there is no such attitude of paying attention to other people's feelings, this kind of homework will not have a greater impact on his character than the Asian mountains mean to his character. "To let the course be recognized and accepted by students, teachers of course must stick to the principle of "Three Closeness", that is, close to reality, close to life and close to students. And conduct in-depth research on the practical problems and theoretical puzzles that students pay attention to, that is, on the basis of in-depth understanding of the needs and expectations of students' development, we should teach students in accordance with their aptitude to meet the personalized needs of students.

\subsection{Transformation of Teaching Discourse Mode}

Habermas put forward the theory of intersubjectivity theory, which regards teachers and students as two independent but symbiotic subjects. Without either party, the inter subjectivity relationship can not be formed. Therefore, under the guidance of this theory, a situation of dual subject discourse and two-way communication comes into being. Educators should respect the discourse expression right of the youth group, respect the cultivation of the subjective personality of the youth group, and realize the two-way communication and sincere communication.

In this inter subjectivity relationship; the relationship between students and teachers is equal communication. Instead of trying to manipulate students and impose their own will on students, teachers respect students' ideas more, mobilize students' subjective initiative, and feel their sense of value in learning and life. For example, the online and offline hybrid teaching mode based on "MOOC + SPOC + flipped classroom" is a teaching method based on the interaction between teachers and students. In the dynamic teaching discourse system, it harmonizes the relationship between teachers and students, and forms a coherent connection of students' learning before class, in class and after class, so as to improve the teaching effect.

Therefore, flipped classroom has the natural cooperation, heuristic, discussion, inquiry and other classroom teaching methods' condition and 
advantages, which opens up an important way for the in-depth reform of classroom teaching.

\subsection{Using Rich and Colorful Teaching Discourse Expression}

The language expression of teaching discourse should be rich and colorful. As the famous linguist Saussure said, before being expressed by words and languages, thought can only be a piece of undefined and indistinct things. Only when language organizes ideas into linguistic symbol sequences can they be perceived and understood by others. If teachers want to convey their ideas to students completely and accurately, they should pay attention to changing the way of language expression and making full use of flexible language symbols to express ideas and feelings.

In order to improve the expressive power of language, teachers should pay attention to the beauty of language rhythm. There are four tones, tonal patterns and rhyming patterns, which form the language rhythm of cadence, undulation, light and dark, alternate with rhyme. The obvious cadence and rhythm is one of the major characteristics of Chinese. The sentence patterns are interspersed with different length, cross and replace, lively and clever, so that the teacher's language has a relaxed and harmonious atmosphere, and it will also attract students, which is embodied in the use of stress, pause and sound change. In the teaching process, in addition to transmitting information through audio language, non-verbal means should be used to help enhance the expression of teaching discourse. These nonverbal symbols include gestures, costumes, actions, eyes, expressions, etc. Taking body language as an example, in the interactive teaching process, in order to enhance the teaching effect, the teacher uses a questioning eye or a searching body to transmit the signal of "I am listening". When the students' language pulse is clear and the language flow is coherent, the teacher will pay more attention to it. When the language pulse is not clear and the language flow is sluggish, teachers should avoid this kind of gaze. More and more studies have shown that non-verbal symbols such as clothing, expression, posture and props have become a strategy of teachers' teaching discourse expression, which often implies a lot of information that can not be ignored.

\subsection{Constructing the Scientific Teaching Discourse Practice Operation Mode}

The teaching discourse practice operation mode of course in Colleges and universities needs the power of all the people involved, mobilizing and integrating all aspects of the force.

First of all, it forms a "six in one" optimization and coordination mode composed of teachers, counselors, professional teachers, party and government cadres, college students and social professional innovation and entrepreneurship personnel as the main force of practical operation mode. Secondly, the relevant business functional departments of education of college students also take responsibility to lead, which can be used as an important leading organization. For example, the party Mass Work Department, propaganda department, educational affairs office, school work office, Youth League Committee, logistics department, etc. Through the form of party class, special subject study and education meeting, evaluation meeting and other forms, we can manage to lead and organize college students to carry out practical teaching, further extend the classroom and improve students' consciousness. Thirdly, some college and department party and league organizations, such as student union, association, party branch, and class committee and so on, should carry out various forms of ideological and political education activities through social practice in winter and summer vacation, community activities and other forms. It can be seen that only by integrating the strength and resources of each part, improving the collaborative mechanism of the joint working conference, coordinating the organizations at all levels of the university and college, and uniting the personnel of all parts to jointly build the "great ideological and political" education system, can it be helpful to build a scientific teaching discourse practice operation mode.

In a word, by integrating teaching content, changing teaching mode, using rich and colorful discourse expression, and creating collaborative and optimized practical operation mode, we can cultivate a kind of comprehensive and practical ability of discourse control field, and constantly improve our own quality and ability in teaching practice, so as to fundamentally improve the pertinence and effectiveness of teaching. 


\section{CONCLUSION}

The smooth development of work in colleges and universities is related to the national development plan. The innovative research and construction of teaching discourse ability of teachers in colleges and universities is the key to carry out the fundamental task of building up people by virtue, and is also the fundamental way to improve cultural soft power and enhance four "self-confidence". This goal has a long way to go, and we must constantly strive for it.

\section{AUTHORS' CONTRIBUTIONS}

This paper is mainly completed by Xiaoliang Guo; Long Xia contributed to revising and editing.

\section{REFERENCES}

[1] Liu Changlin. Chinese System Thinking [M]. Beijing: China Social Sciences Press.

[2] [French] Michel Foucault. Archaeology of Knowledge [M]. Translated by Xie Qiang; Ma Yue. Sdxjoint Publishing Company,2003.

[3] Wu Meng. Foucault's Discourse Theory [D]. Shanghai; Fudan University,2004.

[4] Zhang Yuyu. The Modernization of Marxism and the Construction of the Discourse System of Ideological and Political Theory Courses in Universities [J]. Research on Ideological Education, 2014 (8) : 49.

[5] Yan Xinyue. A Study on the Discourse System Innovation of Ideological and Political Course Teachers in Colleges and Universities from the Perspective of Lide Shuren [J]. Journal of Jilin Institute of Education, 2019 (10) : 63.

[6] Wang Kai. Lenin's Theory of Indoctrination is of great significance to the current Ideological and Political Education in China [J]. Journal of Handan Vocational And Technical College, 2018 (2) : 17-20.

[7] MAO Ya-ping. Research on the Communication of Ideological and Political Education in Vocational Colleges based on Habermas's Communicative Behavior Theory [J]. Journal of Taiyuan City Vocational and Technical College, 2018 (10:8 1-82.
[8] John Dewey. Democracy and education [M]. Trans. Wang Chengxu. Beijing: People's Education Press, 2001:372.

[9] See Dong Tiance. Introduction to Communication [M]. Chengdu: Sichuan University Press, 1995:144. 